\title{
Exploring the contribution of business and technology incubators to women entrepreneurs' business development in Dar es Salaam, Tanzania
}

\author{
Alsen Florian Kapinga ${ }^{1 *}$, Calkin Suero Montero ${ }^{2}$, Godfrey Issac Mwandosya ${ }^{1}$ and Esther Rosinner Mbise ${ }^{1}$
}

\author{
* Correspondence: \\ kamingila@yahoo.com \\ ${ }^{1}$ College of Business Education \\ (CBE), Dar es Salaam, Tanzania \\ Full list of author information is \\ available at the end of the article
}

\begin{abstract}
Women entrepreneurs are key players in the economic development of societies in Sub-Saharan Africa. However, research has reported that business and technology incubators offer insufficient support to their enterprises. Consequently, this paper sets out to explore and highlight the present status of the contribution of business and technology incubators to women entrepreneurs' businesses. The study collected data through exploratory focus group discussions, in-depth interviews, and structured questionnaires. The data were analysed and interpreted using the convergent parallel method. The findings indicate that business incubators provide women's business with training and to some extend enhance their access to market information and business networks. However, the study also finds a lack of contextualisation in the business and technology incubators' services to the real needs of the incubatees, which eventually makes their support less impactful. In this light, the study recommends the provision of incubators' services tailored to the real needs of women businesses. Our work puts forward recommendations to support women entrepreneurs' business development through the contextualisation of the incubators' services tailored to the incubatees' real needs including appropriate training beyond business management. Further investments for establishing new incubation centres are also recommended.
\end{abstract}

Keywords: Women entrepreneurs, Development, Business incubator, Tanzania

\section{Background information}

Women entrepreneurs are increasingly becoming a catalyst in the economic development of the society in Sub-Saharan Africa (SSA) by contributing to their national socio-economic development. The women's business activities contribute to the creation of employment opportunities and the alleviation of poverty (Ihugba \& Njoku, 2014). Okuruf \& Ama (2013) propound that improvement of the investment climate for entrepreneurs, specifically the growth of women's microenterprises, have a great potential for poverty alleviation.

Despite these contributions of women entrepreneurs to economic development, women still face many socio-cultural challenges in their business activities (Kapinga \& Suero Montero, 2017). According to Nchimbi (2002), women entrepreneurs are constrained by numerous social factors such as training, experience, socialization, poor

(c) The Author(s). 2018 Open Access This article is distributed under the terms of the Creative Commons Attribution 4.0 International License (http://creativecommons.org/licenses/by/4.0/), which permits unrestricted use, distribution, and reproduction in any medium, provided you give appropriate credit to the original author(s) and the source, provide a link to the Creative Commons license, and indicate if changes were made. 
networking, discrimination, and unwillingness to take risks. Further, negative attitudes of men towards businesses owned by women pose more challenges in their business development. Women entrepreneurs also experience gender divide and continue to face a number of challenges due to patriarchal practices that situate women in a subordinate position to men (Woldie \& Adersua, 2004). In developing economies, it has been reported that society often neglects and undervalues the education of girls due to patriarchal ideology, which becomes a hindrance in adulthood when they try engaging in business (Amine \& Staub, 2009; Magesa et al., 2013).

Furthermore, women entrepreneurs are confronted with poor infrastructure and lack of space to support the growth of the business (Amine and Staub, 2009). The challenge of working space faced by women entrepreneurs has two aspects: lack of the prime space (city centre) and general lack of space in any area of the city (Jagero \& Kushoka, 2011). Chijoriga (2003) reports that the most critical barriers to women entrepreneurs in Tanzania to start and grow enterprises include limited access to finance, training and markets, lack of appropriate working premises and unfriendly cultural environment. Moreover, women entrepreneurs face problems in accessing business skills and competency development, training, marketing and marketing services, financial service and business networking (Rutashobya \& Nchimbi, 1999).

Recognizing this problem, there have been numerous initiatives to improve women entrepreneurs' business in Tanzania. For example, the Small Industries Development Organization (SIDO) was established under the Act of Parliament No 28 of 1973 to plan, coordinate, promote and offer every form of service to SMEs (Small Industries Development Organization, 2016). On the same vein, the government of Tanzania, in collaboration with the government of Finland, introduced the Information Society and ICT Sector Development Project (TANZICT) whose objectives are to create innovation program and support for incubators in Tanzania (Tanzania Commission for Science and Technology, 2013). Presently, operational business and technology incubators include Dar es Salaam Teknohama Business Incubator (DTBi) and University of Dar es Salaam ICT Incubator (UDICT), which deals with women entrepreneurs and develops innovative ideas from students' final year projects. In addition, Buni Hub and Kinu Hub are also innovation spaces focused on pre-incubation (Cunningham \& Cunningham, 2016).

The problem is, however, that the assessment of the contribution of these incubators in the development of the businesses of women entrepreneurs has received little attention. Hackett \& Dilts (2004) write that the real impact of business and technology incubation is a surprisingly understudied area and hence represents a wide scope for research. In light of this acute paucity of research in the area, the precise extent to which these institutions contribute to the development of women entrepreneurs' business is unclear.

Given the importance of women entrepreneurs to the economic growth of emerging economies, this study stands for exploring the contribution of business and technology incubators to the development of women entrepreneurs' business. Specifically, the study focuses on answering the following questions:

RQ1: What are the roles of business and technology incubators for enhancing the performance of women entrepreneurs' businesses in Tanzania? 
RQ2: What are the unique challenges facing women entrepreneurs in participating in the incubation activities?

RQ3: How can the challenges facing women entrepreneurs be addressed?

This study contributes to the existing body of knowledge in the developing economies, particularly Tanzania, on the roles of business and technology incubators in enhancing the development of women entrepreneurs' owned businesses. We put forward the need for contextualisation of the incubators' services to the real necessities of the incubatees in order to make the incubators' impact stronger. We hope that the findings of this study inform business and technology incubators as well as policy makers in emerging economies in supporting women entrepreneurs in their business activities.

\section{Theoretical perspectives}

Definition of terms

For the purpose of this paper, some key terms and concepts need to be defined at the outset. Marlow and McAdam (2015) defined the concept of the incubator as a site where business founders and those external to it, but embedded within the entrepreneurial endeavour, interact. This is a place where entrepreneurs, business advisors, and external professionals can meet and engage; thus, new firm owners and those acknowledged as experts in shaping and enhancing entrepreneurial legitimacy are positioned in proximity. According to Hackett and Dilts (2004), business incubators are defined as:

"A shared space facility that seeks to provide incubatees with a strategic, value-added intervention system of monitoring and business assistance. This system controls and

links resources and employees, local universities and university community members, industry contacts and professional service providers such as lawyers, accountants, consultants, market specialists, venture capitalists, angel investors, and volunteers".

A business and technology incubator (BTI) is defined as a service that enables businesses to evolve. It is a business development tool for growing entrepreneurial ventures by providing a platform for enterprises to build their foundation. Small Industries Development Organization (2016) defines it as service centres aiming at supporting entrepreneurs who have an innovative and creative business or industrial idea in nurturing such ideas to develop to a level of commercial business undertakings. Business incubators nurture new organizations helping them to survive and grow during the start-up period when they are most vulnerable.

\section{Business incubation and women entrepreneurs' development}

Business incubation is very crucial to the development of women entrepreneurs' business. Business incubators ideally provide women entrepreneurs, as well as all entrepreneurs, with work premises, technical advice, and access to information through ICT facility, financial support through loans, along with other business development services on demand in order to enable smooth start, growth, competitiveness, and sustainability of enterprises (Chijoriga, 2003). Women entrepreneurs could greatly benefit 
from these services as they can develop skills for marketing their products by identifying potential customers and attract them to buy their products.

Business incubation also enables women entrepreneurs to identify potential customers and new markets ${ }^{1}$ where they could sell their products at high prices (Shahzad et al., 2012). Marketing information enables women entrepreneurs to make a sound decision about where and when to sell and at what price, depending on the market demand. Furthermore, business incubators are meant to provide women entrepreneurs with infrastructural facilities such as flexible, affordable working space as well as shared office services ${ }^{2}$ (Kimambo, 2005; Ndabeni, 2008). Moreover, business incubators deliver training related services to women entrepreneurs for capacity building skills. Training could enable women entrepreneurs to acquire relevant skills for production, packaging and marketing their business. Customised training programs for skills development are the most important service for the start-up and business development (Shahzad et al., 2012).

\section{Methods}

\section{Research site and approach}

This study was conducted in Dar es Salaam Region, one of the regions in the eastern part of Tanzania mainland. Dar es Salaam was chosen because it is among the regions with many incubation centres and thriving women entrepreneurs' businesses.

Given the nature of the linkage between women entrepreneurs and business incubators, convergent parallel mixed methods approach was used in order to provide different types of information, detailed views of participants qualitatively and score on instruments quantitatively, yielding results that should be the same (Creswell, 2014). It involved the collection of both qualitative (open-ended) and quantitative (closed-ended) data in response to research questions.

\section{Study population and sampling strategy}

The population of the study was women entrepreneurs dealing with food processing who had been incubated by the Small Industries Development Organization (SIDO). We purposively ${ }^{3}$ chose women entrepreneurs with one-year experience in food processing - because they could provide valuable insights into their business development. A total of fifty-two (52) participants were purposively sampled to participate in the study. Twenty-eight (28) of them joined the focus group discussions, while two (2) of them participated in the in-depth interviews. The two key informant respondents who exclusively participated in the interviews were the general manager from the head office of SIDO (countrywide) and Dar es Salaam regional manager of SIDO. These key informants deal with women entrepreneurs' issues in terms of incubating business from the government viewpoints. Moreover, these managers were included in the study because of their positions as key stakeholders on issues concerning women entrepreneurs, such as training on food processing, provision of working premises, business plans preparations and provision of loans. Fifty (50) out of the 52 participants also filled in questionnaire.

\section{Data collection methods}

In order to ensure validity and reliability, we used different data sources to bolster confidence that data were on the right line; hence, the research instrument would produce 
the same results when used by different researchers (Denscombe, 2010). That is, primary data for the study were collected through in-depth interviews, exploratory focus group discussions (FDGs) and structured questionnaires. The researchers conducted face-to-face interviews with key informants from SIDO in order to obtain in-depth information on their perspectives regarding challenges and opportunities of the business incubators for women entrepreneurs (Kothari \& Garg, 2014). In addition, researchers conducted focus group discussions with four groups of participants, each consisting of seven (7) people. This was done to explore insights, and assertiveness, feelings and ideas about the contributions of business and technology incubation as well as the participants thoughts about business challenges. The sessions lasted 60 to $90 \mathrm{~min}$. Furthermore, a short and simple questionnaire was distributed to and collected from fifty (50) of the participant women entrepreneurs.

Secondary data were obtained from the assessment of the feasibility of women business incubator reports. The objective was to get insights on the role of business and technology incubations and challenges faced by the organizers of the services. In addition, the study also reviewed journal articles and books for definitions background information, gap establishment, methods, limitations and so forth.

\section{Analysis}

Content analysis was used to analyse qualitative data. Content analysis is an approach to the analysis of documents and texts that seeks to quantify the contents in terms of predetermined categories and in a systematic and replicable manner (Bryman, 2012). Hence, this was a very suitable approach to use with our data. Consonant with the approach, the data were organised into categories and themes. On the other hand, quantitative data were analysed using descriptive statistics to ensure a visual representation that is easy to interpret and understand (Denscombe, 2010).

\section{Results}

The results of this study derive from exploratory focus group discussions, structured questionnaires and in-depth face-to-face interviews with stakeholders on the contribution of business and technology incubators to the development of women entrepreneurs' businesses.

\section{Demographic characteristics}

General characteristics of the sample in terms of age, education level, marital status and experience in the business is presented in Table 1. Fifty out of fifty-two respondents volunteered to fill in the questionnaire, twenty-eight out of fifty-two participated in focus group discussion and two key informants participated in the in-depth interview during the data collection process. The participants were 35-44 years old (24 out of 52), married (33 out of 52), had completed tertiary education (21 out of 52), and had six or more years of business experience (20 out of 52). These characteristics were important in our study as they provided information about the background of the respondents that could determine their decision to engage in business activities. 
Table 1 Distribution of respondents by demographic characteristics

\begin{tabular}{lll}
\hline Demographic characteristics & & Number of participants (\%) \\
\hline Age (years) & $18-24$ & $2(4 \%)$ \\
& $25-34$ & $9(17 \%)$ \\
& $35-44$ & $24(46 \%)$ \\
& $45-54$ & $14(27 \%)$ \\
Marital Status & 55 and above & $3(6 \%)$ \\
& Single & $9(17 \%)$ \\
Education Level & Married & $33(63 \%)$ \\
Business Experience & Divorced & $5(10 \%)$ \\
& Primary education & $5(10 \%)$ \\
& Secondary education & $18(35 \%)$ \\
& Tertiary education & $13(25 \%)$ \\
& 1 year & $21(40 \%)$ \\
& $2-3$ years & $14(27 \%)$ \\
$4-5$ years & $9(17 \%)$ \\
& 6 years and above & $9(17 \%)$ \\
\hline
\end{tabular}

Source: Field data (2016)

\section{Roles of business and technology incubators}

To explore research question related to the roles of business and technology incubators in developing the business performance of women entrepreneurs in Tanzania, the study presented the participants with five statements on a five-point Likert scale. The participants were asked to express their opinion by indicating their level of agreement with the statements, where $1=$ strongly disagree and $5=$ strongly agree. The results emanating from this enquiry are summarised in Fig. 1. A detail description of each statement is given here.

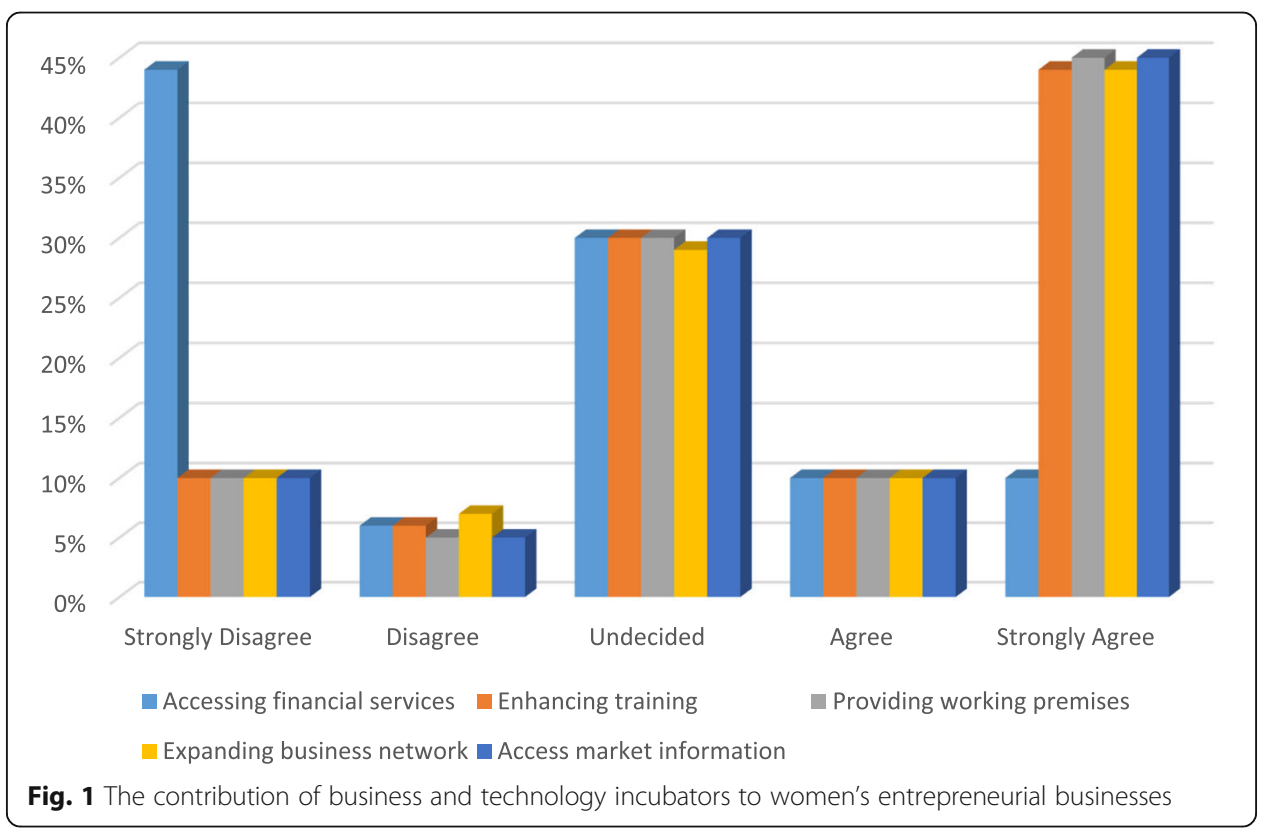


Statement 1: Business incubator contributes to accessing financial institutions

Some participants agreed that business and technology incubators linked women entrepreneurs with financial services. Nevertheless, the majority of the respondents disagreed with or were undecided about this statement (see Fig. 1). In addition, the key informants pointed out that "there is a difficulty for women entrepreneurs to access financial services from financial institutions because they lack collateral in acquisition of loans".

\section{Statement 2: Business and technology incubators facilitate training}

As illustrated in Fig. 1, the majority of the respondents agreed with the statement that business incubators facilitate training for women entrepreneurs. Additionally, results from an in-depth interview with key informants showed that business and technology incubators equipped women with necessary business skills. The results reflect a general satisfaction with business and technology incubators in improving training among women entrepreneurs. However, $30 \%$ of the respondents were undecided about the statement, while, over $15 \%$ showed general discontent with the contribution of business and technology incubators to women's business skills.

\section{Statement 3: Business and technology incubators provide working premises}

The results in Fig. 1 show that the majority of respondents do not consider business and technology incubators as a provider of working premises. Equally, the respondents in the in-depth interviews observed that business and technology incubators lack enough working premises to accommodate a large number of women entrepreneurs. Furthermore, during exploratory focus group discussions, one of the respondents lamented, "the premises provided by SIDO to women entrepreneurs are not enough to allow many women to incubate their business". The responses indicate that business and technology incubators do very little in the provision of the working space to women entrepreneurs in the food processing industry.

\section{Statement 4: Business and technology incubators expand business networks}

As results in Fig. 1 show, over half of the respondents agreed with the statement that business and technology incubators expand their business networks. This is evidence that some stakeholders are generally satisfied with business and technology incubators' service in the area. Nevertheless, about $30 \%$ of the respondents were unsure that this statement was true, whereas, over $15 \%$ of the respondents disagreed with it.

Statement 5: Business and technology incubators enable access to market information

As illustrated in Fig. 1, about half of the respondents believed that business and technology incubators enabled them to access market information. This shows that business and technology incubators play an important role in exposing women entrepreneurs to market, to some extent. However, 30\% of respondents were undecided whether business and technology incubators facilitated this for them, whereas, over $10 \%$ did not believe that this service was actually provided. 


\section{Challenges faced by women entrepreneurs}

To address the research question 'what are the unique challenges facing women entrepreneurs in the business incubators?' we analysed focus group discussions data. The analysis shows that women entrepreneurs process food products at their residences due to the lack of suitable working premises. The in-depth interviews with key informants revealed that there are only four incubation centres in Tanzania, out of which, only one is in Dar es Salaam. Even so, the incubator in Dar es Salaam only accommodates between 25 and 30 women entrepreneurs in one intake.

Furthermore, our findings also show that the lack of conducive working space disqualifies women from getting registrations from institutions such as the Tanzania Bureau of Standards and Tanzania Food and Drugs Regulatory Authority. For example, one participant in the exploratory focus group discussion sessions asserted, "we fail to get a certificate from Tanzania Bureau of Standards (TBS) and Tanzania Food and Drugs Association (TFDA) because we lack premises to conduct our business". Another added, "it is very difficult in Tanzania to get a certificate from TBS and TFDA due to long procedures in obtaining them".

Similarly, one respondent in the in-depth interview said, "availability of working premises is a prerequisite to attaining a certificate of food standards". Overall, women entrepreneurs lack the basic requirements for registration with appropriate authorities.

Another hurdle to women entrepreneurs businesses was found to be the lack of access to financial services. Forty percent of the respondents (40\%) said that business incubators fail to open the doors to financial services suppliers. The members of focus group discussions equally reported that the majority of women entrepreneurs cannot get access to loans from financial institutions for the lack of collaterals.

Regarding business competition, the focus group participants indicated that they face strong competition from producers of similar processed food products. They are also at a disadvantage because the majority of them lack certificates of standards from institutions such as TBS and TFDA, which lock them out of open markets. We noted that failure to compete is also attributed to poor packaging materials and lack of international mark of the standard, which makes the products not attractive to customers.

With respect to marketing strategies, we found that women entrepreneurs lack marketing skills to market their products. One respondent in exploratory focus group discussions asserted, "we lack the skills and strategies of marketing our products in order to win the market". This is a great hurdle considering that winning market involves employing promotional skills to attract customers. The study realised that the existing incubators do not provide training on marketing products.

Figure 2 summarizes the challenges faced by women entrepreneurs, transformation strategies to mitigate the challenges and the target skills needed to improve business performance.

\section{Transformation strategies}

To address the research question 'how can these challenges be addressed in order to enhance women entrepreneurship business development?' data analysis revealed several transversal strategies to leverage their business development in food processing. 


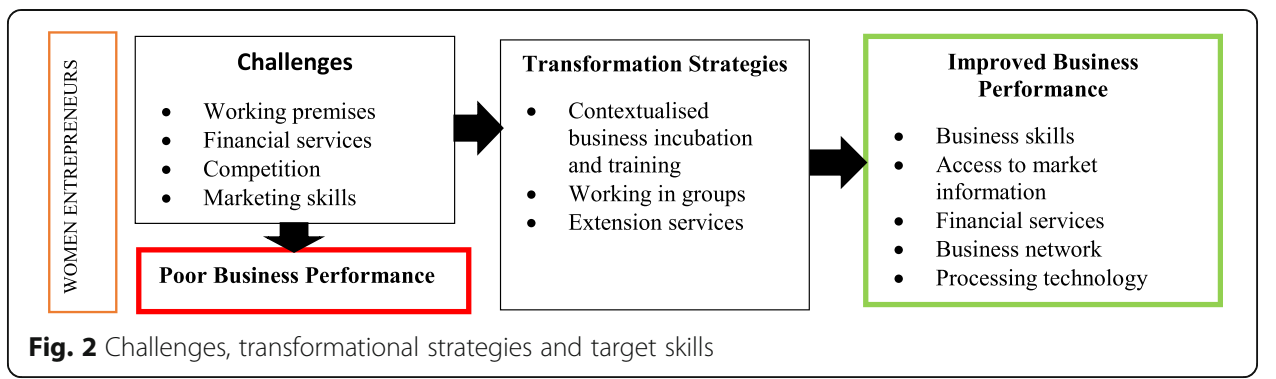

First, we look at contextualised business incubation and training. The majority of the respondents were of the view that the provision of training to develop their business is a panacea to address cross-cutting challenges they faced in their business development. It was observed that women entrepreneurs need a wider range of skills in managing their business in order to be successful. These skills include not only business-related knowledge, such as marketing and management but beyond these, food processing and packaging, as well as mobile technology usage skills. One of the key informants argued that "provision of training is necessary in order to produce a good product and gain competitive advantage". However, incubators should realise that training requirements differ across entrepreneurs. With this regard, incubators need to adapt their training to local contexts to make the offered skills practical to the incubatees' needs. It was observed, for example, that incubators should not only offer business management training to Dar es Salaam women food processors but also practical skills on food processing techniques and methods implementation so that their products meet the expected standards. This contextualisation to the local business environment and situation would make the incubators' work more relevant.

Second, fostering the creation of cooperative groups is important. The study found that creating cooperatives among women entrepreneurs is a strategy to pull up resources together in order to leverage their businesses. Women small cooperatives serve as a forum to discuss issues that constrain their business development such as the lack of capital. Further, the cooperatives offer women with soft small loans for developing their enterprises. Business incubators could thus help women entrepreneurs to create such groups to maximise their opportunities for advice and financial assistance.

Third, we highlight incubator's extension services. Women entrepreneurs continue to get coaching in managing their business even after graduating from business incubators. The study revealed that extension services such as new techniques training should be contextualised to the graduated incubatees needs (e.g., packing style and branding of products). This could enable women entrepreneurs to update skills they actually need in food processing.

\section{Discussion}

Participants in this study included respondents from different age groups, educational levels, marital status and experience in the business. We have realised that these demographic variables have an implication for women to enrol in business incubation. From the sampled women entrepreneurs, respondents of age cohort 35-44 and 45-54 years dominated the population of the study - likely because most of the women at this age are married. As a result, they are charged with household responsibilities and sometimes act 
as families' breadwinners. During the focus group discussions, the participants affirmed that a large number of women engage in business because they are shouldered with multiple domestic responsibilities and in order to upkeep their families they participate in business as a means to earn income.

Data analysis also revealed that the participants in this study had varied levels of education. Whereas some had completed tertiary education, a large number of women entrepreneurs had limited chances to pursue formal learning beyond tertiary education because of cultural constraints embedded in society (see Kapinga and Suero Montero, 2017). The findings also revealed that a significant percentage of participants had vast experience in business with over six (6) years in the practice. Our results suggest that there is a close relationship between demographic characteristics and women entrepreneurs to engage in food processing activities.

The study also affirmed that financial services are vital to the growth of women entrepreneurs' businesses. However, the study revealed that a number of huddles barred women entrepreneurs from getting access to financial services. The study found out, for example, that rigid eligibility criteria in accessing financial services, which include having a registered business, trading license, and business plans make the process of acquiring finance stressful (see also Okuruf \& Ama, 2013; Magesa et al., 2013). The study found that most women entrepreneurs women were not entitled to assets that could be used as collaterals because of strong cultural norms (Magesa et al., 2013; Ascher, 2012). Nevertheless, the study noted a number of initiatives by the government to ensure equal ownership of the property at the household level. All the same, the analysis suggests that more effort is still needed to enforce the initiatives and financial institutions to reduce conditions of lending in order allow more women to access financial services. Moreover, the study sees the need to reverse conservative banking practice by replacing collateral with mutual trust, accountability, participation, and creativity (see, Kumar et al., 2013).

In addition, the study established that training given by the incubators should be contextualised to the local needs of the incubatees. Our study highlights the need for a paradigm change towards the contextualisation of the incubators' services to make them more accessible and relevant to the actual needs in the field of incubatees.

Regarding the perceived importance of business and technology in the expansion of the business network, the results indicate that the incubator has somewhat enabled women entrepreneurs to expand business networks through the interactive programmes they create. Business incubators have become prevalent gadgets for women entrepreneurs' business promotion. The findings of are consistent with Scott et al. (2012) who indicate that expansion of business networks enable women entrepreneurs to access market information about potential customers, market prices and demand for the products. Network pushes women entrepreneurs to expand their external network, the people to whom they sell (Scott et al., 2012). Furthermore, business incubators create a network of relations with other business owners who provide support for each other and who may become customers or suppliers (Ndabeni, 2008). Expansion of business networks is of vital importance to women entrepreneurs in enhancing the market size and earn more income. However, as part of their contextualisation of service practices, incubators should understand better the needs of their incubatees in order to provide services that are of value to all. 
Furthermore, the majority of participants asserted that business and technology incubators do not provide working premise since they lack enough working space to accommodate women entrepreneurs. Most women entrepreneurs perceived the lack of premises as a hindrance to their business development. This is a problem that incubation centres face; for instance in Dar es Salaam Region, SIDO provides working premises to only 25 to 30 incubatees at a time in its headquarters. This deprives women of premises to undertake their business as recommended by the authority responsible for food processing. Our results are consistent with Kyaruzi and Hales (2009) study in Senegal and Tanzania, where they show that accessing appropriate and affordable business premises was a big challenge for most entrepreneurs when setting up their businesses, hence female entrepreneurs operate their business from home and miss opportunities that open market offers. Our results are also consistent with Lose and Tengeh (2015) study in the Western Cape Province, South Africa, who established that business incubator faces challenges of space for production, funding, maintenance of the machine, as well as lack of technical and entrepreneurial skills.

Given their high demand, the incubators are constrained by their incapacity to accommodate a large number of women entrepreneurs to incubate their businesses. The availability of working premises is pre-condition for women entrepreneurs obtain certificates from Tanzania Bureau Standards (TBS) and Tanzania Food and Drugs Association (TFDA), indicating that the quality of the food produced complies with international standards. The food products approved by TBS and TFDA attract more customers increasing sale's volume and profit. However, most of the women entrepreneurs fail to meet basic requirements to obtain certificates of standards. During the focus group discussions, several respondents mentioned that it is very difficult to obtain certificates from TBS and TFDA due to lengthy procedures. They expressed that "we have to observe a lot of conditions and most of us we are processing food products at home premises". Our findings are in line with those of Panda (2018) who observed complications with regulations, complex requirements to register, bureaucracy, and favouritism as impediments to the development of women entrepreneurship in developing countries. As food processing demands special premises in order to avoid contaminations and maintain proper hygiene for human consumption, our study recommends that business incubators should set up new sites to accommodate a large number of clients and eliminate the lack of working premises.

Concerning access to market information, only about half of the participants attributed the services to business incubators. This implies that most women food processors do not receive the needed market information, which is a pre-requisite to compete in a strong competitive market environment and to realise profits in the presence of their counterpart producers of similar products (Kyaruzi \& Hales, 2009). Consequently, we argue that the contextualisation of the incubators' services could make a stronger difference for most of the incubatees when providing access to market information.

\section{Limitations and future research}

Our work exposed the need for tailoring the incubators' services in order to make them relevant to the incubatees. Nevertheless, the results of the study should be interpreted with caution due to the small sample size used. That is, the respondents were all from 
SIDO incubator in Dar es Salaam. Future studies could involve more incubators in Tanzania, such as Teknohama Business Incubator (DTBi) and the University of Dar es Salaam ICT Incubator (UDICT). Likewise, similar studies can be replicated in other countries whose context are more or less similar to the context of Tanzania to test the reliability of the findings of the present study.

\section{Conclusions}

Despite the efforts made by business and technology incubators, women entrepreneurs are still facing an array of challenges that affect their business development. A large number of incubatees still have difficulty to access financial services, have limited working space, are unable to compete in the market, and have limited skills training to develop their businesses successfully. These issues hinder the business growth of the women entrepreneurs in food processing sector in Tanzania. The growth of the businesses depends on a favourable environment that enables women entrepreneurs to produce quality products and create brand loyalty from the market. Our results demonstrate that, to a large extent, the incubatees are disappointed in many of the services provided by business incubators in Tanzania due to their indefiniteness. This underscores the need for tailoring incubators' services to the real necessities of the incubatees in order to make them impactful to the recipients. In addition, plausible strategies to curb the challenges of the incubation activities need to be enforced.

\section{Recommendations}

Based on the experience gained during the field study, the following recommendations are put forward:

- The government should set aside funds in its budget in order to introduce business and technology incubators centres in all the regions of the country. Local incubation centres could reach more women entrepreneurs with business and innovative ideas. At present, SIDO has introduced incubators in four (4) out of twenty-six (26) regions in Tanzania mainland. The implication is that the four incubators cannot suitably accommodate the demands of growing businesses.

- In a competitive business environment, investment in practical training plays a key role in business' success. Consequently, we recommend the provision of practical and contextualised training of business skills to food processing women entrepreneurs in the areas of marketing, food-processing techniques, and packaging of their products.

- The government and other key players should create a favourable environment for women entrepreneurs to improve the quality of processed food products and facilitate the procedure of obtaining quality certificates from relevant authorities. Certificates of standards will build customers' trust and increase market size and profitability to the respective women entrepreneurs. This is, however, not a proposal to lower standards established to protect consumers. Rather, it is a modest proposal to support women entrepreneurs to meet the existing standards. 


\section{Endnotes}

${ }^{1}$ Marketing activities are very important for the success of business in the current hyper-competitive business era (Shahzad et al., 2012).

${ }^{2}$ According to Shahzad et al. (2012), secure and hassle-free workspace environment, affordable office space and prime location are most important to businesses.

${ }^{3}$ According to Bryman, (2012), and Saunders et al. (2009), purposive sampling enable researchers to choose relevant respondents in order to address the research questions of the study. Purposive sampling was also used in order to ensure that a wide cross-section of people was included in the sample and getting the best in-depth information by selecting people most likely to have experience in entrepreneurship domain (Denscombe, 2010).

\section{Acknowledgements}

We want to thank the College of Business Education (CBE) for their support of this research project. Also, we thank the Journal reviewers for their strong recommendations for improving the manuscript.

\section{Funding}

This paper is part of PhD programme at the University of Eastern Finland with the collaboration of College of Business Education, Tanzania. I declare that the source of Fund is College of Business Education (CBE), Tanzania in the design, data collection and interpretation of the results. It is part of student sponsorship allowance which covers to include article writing.

\section{Availability of data and materials}

The datasets used and analysed during the current study are available from the corresponding author on reasonable request.

\section{Authors' contributions}

AFK is the main author of this paper (student at the University of Eastern Finland) He contributed more than the other authors of the manuscript. CSM is the main supervisor and the main guider in writing the manuscript. GIM has contributed in the preparations of the manuscript and reviewing. ERM is a supervisor, guider in writing the manuscript. All authors have contributed in the preparation of the manuscript submitted to the Journal of Global Entrepreneurship Research.

\section{Authors' information}

Calkin Suero Montero (PhD), Senior Researcher at the School of Computing, University of Eastern Finland. She supervise PhD candidate at the edtech Hub-based at the College of Business Education, Dar es Salaam, Tanzania. Contact phone $+358,504,423,789$

\section{Competing interests}

The authors hereby declared that, we have no competing interest in both financial and non-financial.

\section{Publisher's Note}

Springer Nature remains neutral with regard to jurisdictional claims in published maps and institutional affiliations.

\section{Author details}

${ }^{1}$ College of Business Education (CBE), Dar es Salaam, Tanzania. ${ }^{2}$ School of Computing, University of Eastern Finland, Joensuu, Finland.

Received: 5 March 2018 Accepted: 20 August 2018

Published online: 28 August 2018

\section{References}

Amine, L. S., \& Staub, K. M. (2009). Women entrepreneurs in sub-saharan Africa:An institutional theory analysis from social marketing point of wiew. Entrepreneurship and Regional Development:An, 21(2), 183-211

Ascher, J. (2012). Female entrepreneurship-an apropriate response to gender discrimination. Journal of Entrepreneurship, Mnagement, and Innovation, 8(4), 97-114.

Bryman, A. (2012). Social research methods. New York: Oxford University Press.

Chijoriga, M. M. (2003). Report on the Assessment of Feasibility of a Women Business Incubator. Dar es salaam: United Republic of Tanzania,Ministry of Community Development,Gender and Children.

Creswell, J. W. (2014). Research design: Qualitative, quantitative and mixed methods approaches. London: SAGE Publications, Inc..

Cunningham, P., \& Cunningham, M. (2016). Report on Innovation Spaces and Living Labs in IST-Partner. IIMC International Information Mnagement Corporation Ltd (IST-Africa Consortium) [online] Available: http://www.ist-africa.org/home/files/ ISTAfrica_InnovationSpaces_LL_V2_310116.pdf.

Denscombe, M. (2010). The good research guide: For small-scale social research projects. McGraw-Hill Education (UK).

Hackett, S., \& Dilts, D. (2004). A systematic review of business incubation. The Journal of Technology Transfer, 29(1), 55-82. 
Ihugba, O. A., \& Njoku, A. C. (2014). Theoretical analysis of entrepreneurship challenges and prospects in Nigeria. International Letter of Social and Humanistic Sciences, 5 (2014)21-34,ISSN 2300-2697.

Jagero, N., \& Kushoka, I. (2011). Challenges Facing Women Micro Entrepreneurs in Dar es salaam,Tanzania. International journal of Human Resource Studies,ISSN, 1(2), 2162-3058.

Kapinga, A. F., \& Suero Montero, C. (2017). Exploring the socio-cultural challenges of food processing women entrepreneurs in Iringa, Tanzania and strategies used to tackle them. Journal of Global Entrepreneurship Research, 7(1), 17.

Kimambo, C. Z. (2005). Stimulating Small and Medium Enterprises Development for Poverty Reduction through Business and Technology Incubation. In Proceeding of the Discourse on Engineering Contribution in Poverty Reduction (pp. 109-124). Dar es Salaam: University of Dar es Salaam Research Repository.

Kothari, C. R., \& Garg, G. (2014). Research Methodology: Methods and techniques. New delhi: New Age International (P) Limited.

Kumar, D., Hossain, A., \& Gope, M. C. (2013). Role of micro-credit program in empowering rural women in Bangladesh. Assian Bus Rev, 3(4), 114-120.

Kyaruzi, I. S., \& Hales, C. A. (2009). Processes of incubating African female entrepreneurs : Some evidence from Senegal and Tanzania. Journal of Women's Entrepreneurship and Education, 3-4, 42-68.

Lose, T., \& Tengeh, R. K. (2015). The sustainability and challenges of business incubators in the western Cape Province, South Africa. Sustainability, 7(10), 14344-14357.

Magesa, C., Shimba, C., \& Magombola, D. (2013). Investigating impediments towards access to financial services by women entrepreneurs: A case of Arumeru District. Development country studies, ISSN 2225-0565, 3(11).

Marlow, S., \& McAdam, M. (2015). Incubation or induction? Gendered identity work in the context of technology business incubation. Journal of Entrepreneurship Theory and Practice, 39(4), 791-816.

Nchimbi, M. I. (2002). Gender and Entrepreneurship in Tanzania:A comparative Analysis of Male-Female start-Up Motivation Individual characteristics and Perception of Business Success,PhD Thesis. Tanzania: University of Dar es salaam.

Ndabeni, L. L. (2008). The contribution of business incubators and technology stations to small Enterprise development in South Africa. Development Southern Africa, 25(3), 258-268.

Okuruf, F. N., \& Ama, J. O. (2013). Assessing factors that affect women and youth micro-Entreprneurs in Botswana. International Journal of Academic Research in Economics and Mnagement Sciences, 2(1) ISSN:2226-3624.

Panda, S. (2018). Constraints faced by women entrepreneurs in developing countries: Review and ranking. Gender in Management: An International Journal https://doi.org/10.1108/GM-01-2017-0003.

Rutashobya, L. K., \& Nchimbi, M. I. (1999). The African women Entreprneurship:Knowledge gaps and priority areas for future research. In African Entrepreneurship and Small business development.

Saunders, M., Lewis, P., \& Thornhill, A. (2009). Research methods for business students (5th ed.). London: Prentice Hall.

Scott, L., Dolan, C., Johnstone-Louis, Sugden, K., \& Wu, M. (2012). Enterprise and inequality: A study of Avon in South Africa. Entrepreneurship Theory and Practice, 36(3), 543-568.

Shahzad, K., Bajwa, S. U., \& Ali, Q. (2012). Role of incubation in women entrepreneurship development in Pakistan. Asian Journal of Business Management, 200-208.

Small Industries Development Organization. (2016). Business and Technology Incubator Programme. Retrieved from SIDO Web site: http://www.sido.go.tz

Tanzania Commision for Science and Technology. (2013). Annual Report of Activities and Audited Accounts for the Year 2012/13. COSTECH: Dar es Salaam.

Woldie, A., \& Adersua, A. (2004). Female entrepreneurs in a transitional econpomy:Business women in Nigeria. International Journal of Social Economics, 31(1/2), 78-90.

\section{Submit your manuscript to a SpringerOpen ${ }^{\circ}$ journal and benefit from:}

- Convenient online submission

- Rigorous peer review

- Open access: articles freely available online

- High visibility within the field

- Retaining the copyright to your article

Submit your next manuscript at $\boldsymbol{\nabla}$ springeropen.com 